DOI: 10.20472/BMC.2021.012.003

JOSIF GJANI

Faculty of Economics, University of Tirana, Albania

\title{
EUROPEANIZATION AND EU DEMOCRATIC CONDITIONALITY PROCESS IN ALBANIA
}

\begin{abstract}
:
Albania and the European Union (EU) signed the Stabilization and Association Agreement (SAA) in June 2006, which entered into force in April 2009. The main aim of the paper is to discuss on the EU democratic conditionality process in Albania and its relations to 'Europeanization' concept. Aside from Europeanization, the paper examines the opinions of several high EU representatives and local experts regarding the integration process and its political and economic conditionality. It tries to make an analysis also on the present progress and future challenges. European integration, through its democratic conditioning, is a new option for Albania, and it is impacting the internal local governance with new instruments, models and policies.
\end{abstract}

\section{Keywords:}

Europeanization, Albania, EU integration, IPA, European Commission

JEL Classification: A10, E60 


\section{Introduction}

Although the bilateral relations between Albania and the EU were established in 1991, officially the process of Albania's integration into the EU started a decade later, only at the beginning of 2000s. During these years Albania was officially recognized by the European Union as a potential candidate country, while in 2003 the Thessaloniki Summit of EU leaders approved the Stabilization and Association Process, by confirming in this way the EU membership prospect for the Western Balkans countries, including Albania (MEFA, 2020). On the other hand, the integration process is theoretically very much related to the 'Europeanization' process.

Although there are still very few systematic studies on this regard in Albania or in other countries in the Western Balkans region, European integration scholars have noticed that EU has a significant impact on shaping public institutions in setting up new agencies and new coordination procedures within these agencies. The efforts that country shall invest to meet the EU requirements have become increasingly more difficult, given the initial political conditions presented at the Copenhagen European Council in 1993. The formal fulfillment of these conditions in 1993 precedes the invitation for membership negotiations, but in the meantime, the most intensive period for assessing progress and seeing them in practice - including the Commission's monitoring of these conditions - occurs during the accession negotiation phase (Pridham, 2006, p. 377). And though progress has been made in different directions regarding the Albania - EU negotiation process, still the several conditions of European Commission have been extended in different fields.

\section{Aims and research questions}

The main aim of the paper will be to discuss on the EU democratic conditionality process in Albania and its relations to 'Europeanization' concept. Europeanization theory and methods implies studying the process of European integration and not only. It also includes reviewing and revising the impact of EU integration in the local institutions, in the government of the EU potential candidate country and its relations to member states of the European Union. Since it is a very large and broad concept my main research questions will be:

How the 'Europeanization' as a concept is conceived by different EU officials in the context of IPA funds?

Aside from Europeanization, the paper examines the opinion of experts regarding the EU integration process and its political and economic conditionality. It tries to make a analysis also on the present progress and future challenges.

\section{Methods}

In this paper will be included some of the answers and results of the questionnaire developed with local and international IPA experts, working in particular with Albania and other Western Balkans countries. The interviews were coded to maintain the anonymity of the participants who gave their thoughts and opinions on the progress of the process. The questionnaire was semistructured and contained 10 questions. In the first part the questionnaire was structured to get 
some qualitative and quantitative answers regarding the progress of the EU integration process, however it should be noted that these collected data can not be generalized. They serve to the main aims of the paper to give an overview of the demographic data of employees in the civil service, their thoughts and opinions are derived from their daily experience as well as from the difficulties they encounter during their ongoing work. However, this data should also be taken with caution, firstly because many of them are part of the EU integration process and as an insider they may not have the same view as someone who is an independent expert and stays out of the process. Also their demographic data, such as age, education and years of employment, also due to the low number of respondents can not create a profile of employees in the project or IPA instrument. However, I can mention one fact, that most of them are employed at high, managerial levels, and that they mainly stay in important executive positions and as such can help us to understand better IPA implementation and challenges during the process.

\section{Negotiations and the EU integration process}

As it was mentioned in the introduction, Albania started its EU integration process officially at the begginign of the 2000s with the signing of the Stabilization and Association Agrement (SAA). In June 2006, the negotiation process was concluded, and the SAA entered into force on 1 April 2009, the year in which' Albania formally applied for EU membership '(MEFA, 2020). 'In November 2009, based on the questionnaire that the European Commission submitted to Albania regarding the country's preparation for membership, started the negotiations for obtaining the status of candidate country. On June 27, 2014, Albania received the status of candidate country. But in the meantime, the Council set out five key priorities: 1) public administration, 2) rule of law, 3) the fight against corruption, 4) organized crime, and 5) the fundamental rights that Albania had to fulfill before accession negotiations could begin' (Ibid.).

\section{EU criteria and democratic conditionality}

EU's democratic conditionality is based on the 'reward-enhancing strategy' by which the EU provides external incentives for targeted governance policies in case they meet its conditions (Schimmelfennig \& Sedelmeier, 2004). The attraction to a possible EU membership, as well as the opening negotiations, serve as a strong incentive for countries that aspire to be integrated in EU. As Geoffrey Pridham (2006) describes it, in other words, the whole process of EU democratic conditionality is based on a dynamic that contains risks in case of stepping back from the process, not only for potential countries local governments but also for the EU institutions.

In the last twenty years, the Albanian EU integration process has been going forward and backward. One of the major steps on this process was on 9 November 2016 when based on the fulfillment of conditions in several fields such as the public administration, rule of law, war against corruption, organized crime and the promotion of the human rights, the Commission proposed to open the negotiations with Albania. This proposal it was based as well on the progress on the judicial reform, which has been put as a capstone in the last negotiations with the EU. But, however two years later, other conditions were added. In its annual Enlargement Policy, the European Commission decided to recommend the opening of the negotiations with Albania in light of the progress made and deepening of the given reforms. Some months later, on June 26, 
2018, the EU General Affairs Council agreed to respond positively to the progress made by Albania and to determine the path to the opening of membership negotiations (Albanian Ministry of Europe and Foreign Affairs, 2020).

Adhering to the theoretical analysis of historical institutionalism, the integration process is an important 'process', and which suggests some features or characteristics of policy-making and decision-making at the European and candidate country level. 'Firstly, [historical institutionalism] suggests that policy-making is better understood as a summative process rather than a series of separate events. What happens in the past shapes the possibilities of the future. Thus, instead of pursuing some rational strategic objectives, actors should spend more time working with previous institutional choices 'history creates the context that shapes elections' (Jordan, 2002, p. 52). Secondly, as EU rules evolve in a policy sector, they are more likely to collide (or not stand) with pre-existing national institutional forms. In terms of the development of the process, integration and Europeanization are, in fact, the result of a constant battle between the various institutions rooted in the integration process, one at the European level and the other at the national level (Ibid, p.53). But while there is a need for an incorporation of EU rules and Europeanisation at the local level, again the effectiveness of EU integration policies can only be explained by the 'model of external incentives and especially by the credibility of EU conditionality and the internal costs of adopted the rules. However, the impact of these conditions varies depending on the context of the external condition. Thus, usually an authoritarian governments rejects the membership offer rather than accepting the political costs of adopting liberal democratic rules (Schimmelfennig \& Sedelmeier, 2004, p. 663). Different researchers mention the case ofCentral and Eastern European countries and the fact that their EU integration process took place at the same time as they began to democratize (Pridham, 2006, p. 378). The years of transition for these countries, and for Albania, began before the start of the negotiation process during the years 1998/2000, although they had established some trade relations with the EU, and Albania had benefited from several financial and humanitarian assistance programs.

During the 1990s, the EU went beyond the democratic conditionality used for Southern Europe, and beyond the Copenhagen criteria as defined during 1993 and that included only three main conditions: (1) the stability of democratic institutions, (2) the rule of law, and (3) respect for human and minority rights. In the meantime there were added economic, social and cultural rights such as the independence of the judiciary, anti-corruption measures, the further elaboration of a range of human and minority rights (especially underlining the extreme conditions of the Roma population). Furthermore it is put as a democratic conditionality as well the trafficking of women and children and gender equality (Ibid.). More over, democratic conditionality became more specific based on the problems of each country. By taking in consideration and analyzing the most recent European Commission democractic conditionality for Albania, the conditions for the year 2020 included: (1) Electoral Reform; (2) Judicial Reform; (3) fight against corruption; (4) fight against organized crime. Other issues were the anti-defamation law, public administration reform, the transparency of civil service etc. (Ivkovic, 2020).

\section{Discussion and analysis}

According to Schimmelfennig \& Sedelmeier (2004) exist three models of EU external governance: (1) External Incentive Model; (2) Social Learning Model; (3) The Lesson Learned Model (p. 663). 
For them, the EU has chosen to use the model of external incentives for Central and Eastern European countries, which is a model is at odds with the other two models. The actors in this model are presumed to be strategic maximizers of their interests for power and well-being. In the negotiation process they exchange information, threats and promises; and their outcome will depend on their negotiating power. For Schimmelfennig \& Sedelmeier (2004), the starting point of the negotiation process is the status quo, which is conceived as an 'internal balance' and reflects the distribution of preferences and the bargaining of power in society. EU conditionality distresses this internal balance by presenting incentives to meet EU conditions. Conditionality affects the targeted government directly or through intergovernmental negotiation or indirectly through the differentiated empowerment of internal actors. In the latter case, democratic conditions change the internal governing structure of potential member countries by supporting with incentives those actors who are in favor of adopting EU rules and strengthening them compared to their opponents in society and in governance.

However, in the end, the adoption of rules requires an authoritarian decision-making of the targeted government which seeks to balance the EU, domestic and international pressure in order to maximize its political benefits' (Schimmelfennig \& Sedelmeier, 2004, p. 664). The authors, Schimmelfennig \& Sedelmeier (2004) also point out that the transfer and adoption of EU rules is also affected by the 'speed' and 'size' of the reward (Ibid.). Other issues raised by the authors relate to the credibility of the 'reward' and 'threat' from the EU, the actors who have the right of 'veto' and the costs of admitting new countries to the EU. For this reason they formulate two alternative models of EU external governance, the social learning model and the lessons learned model (Schimmelfennig \& Sedelmeier, 2004, p.667). But before analyzing these two models, it is important to analyze the role of the Commission in the delivery and management of financial assistance. It is important to assess that only the European Commission already has the formal power to initiate and draft legislation, including the right to amend its proposals at any stage of this process, and also serves as a think tank for new policies (Article 221 of the Treaty establishing the European Community) (Hooghe \& Marks, 2001, p. 12). Even today, the role of the European Commission, which has a central role in the implementation of the IPA financial instrument and its internal political-administrative dynamics have received less attention from research in the fiueld of EU budget than for example studies for the Council of Europe and the European Parliament (Goetz \& Patz, 2016, p.1041). EU Treaties have assigned the Commission a central role in the execution of the EU budget (EU Treaty, 2008). It has additional responsibilities regarding the drafting of the annual budget and the right to amend the draft at later stages of the budgeting process. The European Commission also has a further duty to act as a moderator between the Council and the European Parliament in inter-institutional negotiations (Ibid.) And has the right to participate throughout the budget drafting and approval process. This exclusive right to propose EU legislation, and other rights to amend proposals until the Council of Europe acts, have given the European Commission a very important role. But the fact that the role of the Commission has not attracted the interest of scholars can be attributed more to the fact that it has an intermediate role and is often considered a 'bureaucratic actor'. As a result, the high-level political conflicts of member states' leaders within the Council of Europe and the power disputes between the Council and the European Parliament over EU spending have been more promising, even in studies that have recognized the important role of the Commission. Recent studies on the process of drafting the annual budget since the entry into force of the Lisbon Treaty focus almost 
exclusively on the balance of power between the European Parliament and the Council, seeing a shift of power towards the latter, based on the analysis of change. in formal decision-making rules (Goetz \& Patz, 2016, p.1042). On the other hand, the European Commission, through the instruments used in its foreign policy and financial assistance instruments, can influence and condition the accession process into five main categories:

- Filtering: setting a standard for EU accession and the later stages of the accession process - this is one of the most powerful EU conditional tools in the accession process and in particular with the granting of candidate country status and the start of negotiations. Aid, trade and other benefits can be used to promote domestic policy changes in countries wishing to join, but they do not have such a visible and direct result as progress towards membership. It took the EU many years, almost a decade, to develop such a condition. When the Copenhagen criteria were set in 1993, it was not clear which elements of the political and economic conditions had to be met for an applicant country to join the EU. The stages of the negotiation process were also defined at the meetings of the Council of Europe in Luxembourg (1997) and Helsinki (1999).

- $\quad$ Privileged access to trade and additional assistance;

- Signing and implementing an extended form of accession agreement (Europe Agreements for candidate countries, Stabilization and Association Agreements for Southeast European countries and other non-applicant countries);

- Opening of negotiations (subject to fulfillment of conditions for democracy and human rights since 1999);

- Opening and closing of 31 chapters;

- $\quad$ Signing of the accession treaty;

- Ratification of the accession treaty by the national parliaments and the European parliament;

- $\quad$ Adherence as a full member (Grabbe, 2011, p. 1020)

\section{Main findings and results}

In regards to European integration of Albania it has been analyzed in relation to the implementation of IPA funding from the European Commission. As it was mentioned at the beginning, in this part of the paper will be included different comments and suggestion regarding EU funding policies in potential member countries. Thus, respondents generally feel that IPA has contributed to all aspects of the market economy in Albania by addressing key challenges and providing opportunities for improving the economy. According to them, IPA has provided assistance in terms of legislation and for the implementation of major investment projects.

All interviewees had knowledge about the main goals and objectives of IPA and are aware of the six sectoral programs in which sectoral budget support has been implemented. Some of them, regarding budget support, emphasize that its implementation is a challenge for the public administration due to the complexity of the entire programming and implementation period. But over time, and the more experience the interviewees have with this procedure, the easier and more satisfying its implementation becomes. It is also mentioned that different interviewers mention the fact that the sectoral strategic documents in which they belong and that they have prepared or participated in their drafting and evaluate the positive sides of these strategies and the connections that these strategies have with budget support. IPA II, according to most 
respondents has contributed in a significant way to undertaking structural reforms in the country. Among the most important impacts are the improvement of policy-making for different sectors of the economy. While the budget support highlights the difficulties and that in general is a mechanism that has provided evidence that brings benefits to the management of EU funds accurately.

Each of the interviewees responded that they have a conceptual map of their location in the IPA instrument, the strategic program of their sector and its relationship with other sectors of the economy. In this context, some of them consider that a greater approximation is needed in terms of national priorities. According to them, this can be achieved by linking concrete support to larger sectoral projects that contribute to achieving these objectives. Some of the respondents emphasize that there should be a greater dissemination of information on how the IPA program works, including the programming of the medium-term budget project and co-financing funds, as well as providing a sufficient budget to implement the targeted indicators in budget support. Regarding disbursement, one of the respondents commented that the disbursement rate can be improved by simplifying procedures and bureaucracies and building on previous successful cases and using them as models to succeed in other upcoming projects. Most of the respondents are aware that budget support in Albania has a strong sectoral approach and which includes many institutions for its implementation and that coordination and cooperation between institutions should be improved. Line ministries are not the direct beneficiaries of disbursement tranches because it goes to the state budget.

Regarding the implementation of budget support, interviewers are divided on the pros and cons. Among the advantages or disadvantages is the fact that the administration learns how to manage EU funds and is prepared for their future management when it becomes part of the EU but on the other hand, among the disadvantages, the need for a series of procedures and many efforts by the public administration in order to meet the set criteria. According to them, this has caused an unnecessary consumption of time.

In general, among the main criteria for successful budget support is the institutional framework and coordination between institutions and the sharing of information between them. The budget planning phase is mentioned by many interviewees, especially in terms of transparency, and the fact that budget priorities should be planned in advance as well as the priorities should be related to specific sectors and monitored continuously. And in terms of the strategic approach, the links between strategies and strategic documents are very important for a successful sectoral budget support approach.

\section{Conclusions}

Albania and the European Union (EU) signed the Stabilization and Association Agreement (SAA) in June 2006, which entered into force in April 2009. This document reflects Albania's path towards the country's association and membership in the EU, but at the same time meant that Albania would also benefit from financial assistance instruments in a structured manner and not as part of humanitarian aid and emergency situations as had happened in the 1990s. Throughout the 1990s, the EU went beyond the democratic conditionality used for Southern Europe, and beyond the Copenhagen criteria. Other criteria such as economic, social, cultural rights and more specific criteria were used in each potential candidate country. 
In general, it can be concluded that the EU integration process for Albania has been based on the concepts of democratic conditioning and Europeanization. These concepts have been primary and supported by the EU's external financial incentive policies, of which the IPA program is a part. European integration, through its democratic conditioning, is a new option for Albania, and it is impacting the internal local governance with new instruments, models and policies.

\section{References}

Albanian Ministry of Europe and Foreign Affairs . (2020). Faqja zyrtare e Ministrisë për Evropën dhe Punët e Jashtme. Retrieved from Marrëdhëniet Shqipëri- BE: http://integrimi-nebe.punetejashtme.gov.al/anetaresimi-ne-be/historiku/

Goetz, K. H., \& Patz, R. (2016). Pressured budgets and the European Commission: towards a more centralized EU budget administration? Journal of European Public Policy, 1038 - 1056.

Grabbe, H. (2011). How does Europeanization affect CEE governance? Conditionality, diffusion and diversity . Journal of European Public Policy. Vol.8 (6) , 1013-1031.

Hooghe, L., \& Marks, G. (2001). Multi-Level Governance and European Integration . Oxford : Rowman \& Littlefield Publishers, Inc. .

Ivkovic, A. (2020). Albania's homework: What are the conditions for the next step towards the EU? Retrieved from European Western Balkans : https://europeanwesternbalkans.com/2020/04/08/albanias-homework-what-are-the-conditionsfor-the-next-step-towards-the-eu/ Jordan, A. (2002). The Europeanization of British Environmental Policy. London: Palgrave Macmillan.

Pridham, G. (2006). European Union Accession Dynamics and Democratization in Central and Eastern Europe: Past and Future Perspectives. Government \& Opposition, 41(3), 327-468.

Schimmelfennig, F., \& Sedelmeier, U. (2004). Governance by conditionality: EU rule transfer to the candidate countries of Central and Eastern Europe . Journal of European Public Policy, 661 -679 . 